\title{
First report of Cytospora chrysosperma causing canker on staghorn sumac in China
}

\author{
Zhe Wang $^{1} \cdot$ Hai-ting Hao ${ }^{1} \cdot$ Shuai-shuai Sha ${ }^{1} \cdot$ Sha-sha Peng ${ }^{1} \cdot$ Xin-ru Zhang ${ }^{1} \cdot$ Lan Wang $^{1} \cdot$ Hong-zu Feng $^{1}$
}

Received: 28 November 2021 / Accepted: 1 February 2022 / Published online: 8 February 2022

(c) The Author(s) 2022

Keywords Canker $\cdot$ Cytospora chrysosperma $\cdot$ Rhus typhina $\cdot$ Multilocus sequence analysis

Staghorn sumac (Rhus typhina) is an exotic plant widely distributed in China. During 2020, a canker disease has been observed on approximately $40 \%$ of staghorn sumac in Alar area, Xinjiang $\left(40^{\circ} 32^{\prime} 46^{\prime \prime N}, 81^{\circ} 17^{\prime} 34 " \mathrm{E}\right)$, China. The affected branches were yellowish-brown, and the inner bark was black. Under moist conditions, spore masses jutted out in long, reddish-orange, coiled tendrils. Samples were collected from nine symptomatic trees. The pathogen was isolated from surface-disinfected tissues and incubated on PDA medium at $26{ }^{\circ} \mathrm{C}$ for 5 days. Colonies had whitishorange, fluffy mycelium. Multilocules (with common walls) were arranged irregularly around the stroma. Conidiophores and monospores were hyaline, the latter slightly curved, 3.7-6.6×1.1-1.9 $\mu \mathrm{m}(\mathrm{n}=20)$. Genomic DNA was extracted from the representative isolate ALE04. The internal transcribed spacer (ITS) region of rDNA, transcription elongation factor (tef- $1 \alpha$ ) and $\beta$-tubulin (tub2) gene portions were sequenced using ITS1/ITS4, EF1-728F/EF1-986R and Bt2a/ $\mathrm{Bt} 2 \mathrm{~b}$ primers, respectively (Zhang et al. 2014). The obtained sequences were deposited in GenBank (accession numbers OK275544, OK382944 and OK382949 for ITS, tef-1 $\alpha$ and

Zhe Wang and Hai-ting Hao are co-first authors.

Lan Wang

wang-lan95@163.com

$\triangle$ Hong-zu Feng

fhzzky@163.com

1 Key Laboratory of Integrated Pest Management of Xinjiang Production and Construction Corps in Southern Xinjiang/ Scientific Observing and Experimental Station of Crop Pests in Alar from Ministry Of Agriculture and Rural Affairs/The National and Local Joint Engineering Laboratory of High Efficiency and Superior-Quality Cultivation and Fruit Deep Processing Technology of Characteristic Fruit Treesin Southern Xinjiang, Tarim University, Alar 843300, People's Republic of China tub2, respectively). Phylogenetic analysis of the combined ITS, tef- $1 \alpha$ and tub2 sequences of the ALE04 isolate and the reference strains of same and closely related species was done using the maximum likelihood method. Based on the phylogenetic analysis and morphological characterization, the isolate ALE04 was identified as Cytospora chrysosperma (Pers.) Fr.. Inoculation of 1-year-old twigs of staghorn sumac proved the pathogenicity of $C$. chrysosperma isolates. Pathogenicity tests were repeated five times. The typical canker symptoms appeared after 15 days, and the same fungus was re-isolated from all inoculated branches. No lesions developed on the control branches. Currently, the proven hosts of C. chrysosperma in China are Castanea, Populus, Morus, Salix, Ulmus, and Juglans genera (Fan et al. 2015). To our knowledge, this is the first report of pathogenic C. chrysosperma occurrence on R. typhina in China (Farr and Rossman 2021).

Supplementary information The online version contains supplementary material available at https://doi.org/10.1007/s42161-022-01059-5.

Acknowledgements The authors would like to express their gratitude to EditSprings (https://www.editsprings.cn/) for the expert linguistic services provided.

Funding information This study was funded by The Joint Funds of the National Natural Science Foundation of China (Grant No. U1903206); project supported by The State Key Laboratory of Crop Stress Biology for Arid Areas, NWAFU (Grant No. CSBAA2020009); Project of Scientific Research and Innovation for postgraduates in Xinjiang Uygur Autonomous Region (Grant No. XJ2021G293).

\section{Declarations}

Conflict of interests There are no potential conficts of interest, and this research is not involved with any Human Participant or Animal. All authors have approved the submission of this manuscript. 
Open Access This article is licensed under a Creative Commons Attribution 4.0 International License, which permits use, sharing, adaptation, distribution and reproduction in any medium or format, as long as you give appropriate credit to the original author(s) and the source, provide a link to the Creative Commons licence, and indicate if changes were made. The images or other third party material in this article are included in the article's Creative Commons licence, unless indicated otherwise in a credit line to the material. If material is not included in the article's Creative Commons licence and your intended use is not permitted by statutory regulation or exceeds the permitted use, you will need to obtain permission directly from the copyright holder. To view a copy of this licence, visit http://creativecommons.org/licenses/by/4.0/. with description of a new species $C$. gigalocus. Fungal Biol 119(5):310-319. https://doi.org/10.1016/j.funbio.2014.12.011

Farr DF, Rossman AY (2021) Fungal Databases, U.S. National Fungus Collections, ARS, USDA. Retrieved November 23, 2021, from https://nt.ars-grin.gov/fungaldatabases/

Zhang MX, Zhai LF, Xu WX, Hong N, Wang GP (2014) First Report of Valsa leucostoma Causing Valsa Canker of Pyrus communis (cv. Duchess de' Angouleme) in China. Plant Dis 98(3):422. https:// doi.org/10.1094/PDIS-07-13-0704-PDN

Publisher's Note Springer Nature remains neutral with regard to jurisdictional claims in published maps and institutional affiliations.

\section{References}

Fan XL, Kevin DH, Liu M, Liang YM, Tian CM (2015) Cytospora species associated with walnut canker disease in China, 